\title{
Primary Lung Meningioma
}

National Cancer Institute

\section{Source}

National Cancer Institute. Primary Lung Meningioma. NCI Thesaurus. Code C5276.

A rare meningioma that is present in the lung without clinical or radiologic evidence of central nervous system involvement. 